\title{
ДЕРЖАВНЕ РЕГУЛЮВАННЯ РОЗВИТКУ РЕЦИКЛІНГУ ПОБУТОВИХ ВІДХОДІВ В УМОВАХ ЕКОЛОГІЗАЦІЇ ЕКОНОМІКИ
}

Левченко Н.М., д-р наук з держ. упр., професор, Національний університет «Запорізька політехніка», м. Запоріжжя, Україна

Жовнірчик Я.Ф., д-р наук $з$ держ. упр., професор, Національний авіаційний університет, м. Київ, Україна

У статті акиентовано увагу на основних проблемах поводження з побутовими відходами. Обтрунтовано критичність ситуації поводження з побутовими відходами та встановлено причини ї̈ виникнення. Доведено потребу пошуку шляхів посилення дієвості механізмів державного регулювання поводження з побутовими відходами та можливостей імплементації європейського досвіду у вітчизняну практику. Акцентовано на відповідальності об'єднаних територіальних громад за надання комунальних послуг з поводження з відходами та стан довкілля. Наголошено, щзо рециклінг відходів у зарубіжній практиці є однією з найбільш прибуткових галузей економіки. Констатовано, щзо перші спроби бізнес-рециклінгу в Украӥні завершились провалом з причин відсутності дієвих механізмів державного регулювання поводження з побутовими відходами. Уточнено зміст поняття «побутові відходи» иляхом формування авторського визначення за відновлювальним підходом. Визначено відмінні риси відходів та вторинних ресурсів. Розглянуто основні законодавчі акти з питань регулювання поводження з відходами та доведено їх неефективність. Опрацьовано за Національною стратегією управління відходами в Україні до 2030 року основі принципи поводження з побутовими відходами. Обгрунтовано доцільність запровадження рецииклінгу відходів на прикладі Полтавського субрегіону, виокремленого від- 
повідно до Субрегіональної стратегії поводження з відходами у Полтавській області, розробленій європейськими експертами за nidтримки Deutsche Gesellschaft für Internationale Zusammenarbeit (GIZ) GmbH у рамках міжнародного проекту «Реформа управління на сході України» (PN 11-2129.2-001.00). Доведено необхідність виокремлення рециклінгу відходів в окрему галузь економіки, що забезпечить дотримання, взятих Украӥною зобов'язань щооо екологізачії економіки. Розроблено практичні рекомендації щуодо розробки об'єднаними територіальними громадами Концепщії взаємодї об'єднаних територіальних громад з учасниками прочесу рециклінгу побутових відходів.

Ключові слова: відходи, тверді побутові відходи, муніциипальні відходи, рециклінг відходів, екологізація економіки.

Постановка проблеми у загальному вигляді. Реалізація реформ місцевого самоврядування потребує ефективного вирішення проблем місцевого розвитку, серед яких особливе місце займає питання управління (збирання, перевезення, зберігання, сортування, утилізація та видалення, знешкодження та захоронення) побутовими відходами [1, с.310].

Значні обсяги накопичених відходів на територіях об'єднаних територіальних громад (далі - ОТГ), відсутність ефективних заходів, спрямованих на запобігання їх утворенню, рециклінгу, відновленню та видалення, ускладнюють екологічну ситуацію територіальних громад та стають гальмівним фактором розвитку їх економіки. Причинами тому загальновизнано:

- низький рівень урегульованості на законодавчому рівні питань управління відходами;

- інституційна неспроможність територіальних органів;

- недостатній рівень взаємодії ОТГ, територіальних органів ДФС та територіальних органів Держекоінспекції;

- відсутність джерел фінансування на здійснення екозаходів тощо.

Все перелічене беззаперечно призводить до збільшення кількості несанкціонованих сміттєзвалищ та перевантаження поліго- 
нів, що є прямою загрозою як довкіллю, так і здоров’ю та якості життя населення.

Аналіз останніх досліджень і публікацій засвідчує, що критичний стан поводження з побутовими відходами не залишає байдужими як практиків, так і науковців. Питання державного втручання в управління поводження з побутовими відходами не перший рік досліджуються такими науковцями, як В. Бебик, С. Довгий, М. Михальченко, А. Новицький, В. Цимбалюк та ін. Проте, незважаючи на цінність результатів їх досліджень, питання управління побутовими відходами до тепер не втрачають своєї актуальності, а навпаки, $з$ підписанням Угоди про асоціацію між Україною, 3 однієї сторони, та Європейським Союзом, Європейським співтовариством 3 атомної енергії і їхніми державами-членами, 3 іншої сторони (далі - Угода), за якою Україна взяла на себе зобов'язання 3 впровадження положень (Рамкової) Директиви №2008/98/СС Свропейського парламенту та Ради від 19 листопада 2008 р. «Про відходи та скасування деяких директив» [22] у національне законодавство, а також $з$ ратифікацією міжнародного стандарту ISO 26000/2010 «Керівництво 3 соціальної відповідальності» [31] та 3 практичним завершенням територіальної децентралізації набувають нового змісту, що саме і обумовлює необхідність в їх подальших дослідженнях.

Формулювання цілей статті (постановка завдання). Метою статті $є$ вивчення стану державного регулювання розвитку рециклінгу побутових відходів в умовах екологізації економіки та пошук шляхів посилення дієвості його інструментарію.

Виклад основного матеріалу дослідження. Важливість та актуальність питання поводження 3 твердими побутовими відходами (далі - ТПВ) зумовлена досить гострою ситуацією, що склалась у сфері поводження з ними. За офіційними даними Державної служби статистики України обсяги накопичених ТПВ за областями протягом 2018 року склали (табл.1): 
Таблиця 1

\section{Обсяги накопичених в Україні твердих побутових відходів на полігонах та сміттєзвалищах протягом 2018 р. [3]}

\begin{tabular}{|c|c|c|c|c|c|c|}
\hline \multirow{3}{*}{ Область } & \multirow{2}{*}{\multicolumn{2}{|c|}{$\begin{array}{c}\text { Обсяги захоронення } \\
\text { на полігонах (звали- } \\
\text { щах) - всього }\end{array}$}} & \multicolumn{4}{|c|}{ у тому числі } \\
\hline & & & \multicolumn{2}{|c|}{$\begin{array}{c}\text { від початку екс- } \\
\text { плуатації полігонів } \\
\text { (звалищ) }\end{array}$} & \multicolumn{2}{|c|}{ за звітний період } \\
\hline & м3 & $\mathbf{T}$ & M3 & $\mathbf{T}$ & M3 & $\mathbf{T}$ \\
\hline Вінницька & 30712461,2 & 6127226,3 & 29379092,3 & 5889129,7 & 1333368,9 & 238096,6 \\
\hline Волинська & 14071125 & 3860345 & 12908425 & 3688752 & 1162700 & 171593 \\
\hline Дніпропетровська & 39214256,8 & 6512256 & 33596207,3 & 5672628,1 & 5618049,5 & 839627,9 \\
\hline Донецька & 116389839,9 & 29022676,7 & 113382229,2 & 28153316,7 & 3007610,7 & 869360,0 \\
\hline Житомирська & 25244551,3 & 6749307,3 & 23899872 & 6448425,6 & 1344679,3 & 300881,7 \\
\hline Закарпатська & 10486209,8 & 3269277,1 & 9230817,5 & 2971422,3 & 1255392,3 & 297854,8 \\
\hline Запорізька & 48329696 & 12107336,1 & 44837315 & 11525272,1 & 3492381 & 582064 \\
\hline Івано-Франківська & 15801772,7 & 3684538,1 & 14879262 & 3513798 & 922510,7 & 170740,1 \\
\hline Київська & 25752956,9 & 44320887,2 & 24529733,8 & 44114539,8 & 1223223,1 & 206347,4 \\
\hline Кіровоградська & 16818683,3 & 4041528,9 & 14784466,6 & 3431263,9 & 2034216,7 & 610265,0 \\
\hline Луганська & 14518574,3 & 3816962,3 & 13895358,0 & 3671120 & 623216,3 & 145842,3 \\
\hline Львівська & 577193039,4 & 7363933,3 & 573381821,5 & 6715983,0 & 3811217,8 & 647950,2 \\
\hline м. Київ & 46013950,2 & 12367832,2 & 42679247 & 11629582,2 & 3334703,2 & 738250,0 \\
\hline Миколаївська & 69450000 & 14772600 & 68300000 & 14543100 & 1150000 & 229500 \\
\hline Одеська & 12481375,4 & 3120343,1 & 6383803 & 1595950 & 6097572,4 & 1524393,1 \\
\hline Полтавська & 41694435,6 & 8045856,3 & 39931856,1 & 7695657,1 & 1762579,5 & 350199,2 \\
\hline Рівненська & 32951064 & 7693398,3 & 31843483,7 & 7500070,6 & 1107580,3 & 193327,7 \\
\hline Сумська & 12513625,8 & 415314,9 & 11750335,6 & 219600,4 & 763290,2 & 195714,5 \\
\hline Тернопільська & 22194772 & 5484775 & 21430910 & 5316610 & 763862 & 168165 \\
\hline Харківська & 77216590,2 & 15294366,7 & 73482908,9 & 14637367,1 & 3733681,3 & 656999,6 \\
\hline Херсонська & 27759106 & 8180191 & 26979244 & 7970729 & 779862 & 209462 \\
\hline Хмельницька & 45751076,4 & 9370638,5 & 44162409,4 & 9128615,8 & 1588667,0 & 242022,7 \\
\hline Черкаська & 14283078 & 2750796 & 13172710 & 2529606 & 1110368 & 221190 \\
\hline Чернівецька & 10470806,2 & 974802,7 & 9625939,3 & 949208,9 & 844866,9 & 25593,8 \\
\hline Чернігівська & 32880907,1 & 8088614,6 & 31753130,4 & 7861099,8 & 1127776,7 & 227514,8 \\
\hline Всього по Україні: & 1380193954 & 227435804 & 1330200578 & 217372848 & 49993376 & 10062955 \\
\hline
\end{tabular}


Дані табл. 1 переконливо засвідчують, що ситуація 3 побутовими відходами набула катастрофічних масштабів. Сміттєві полігони вже зараз займають близько 3 \% усієї території країни і продовжують збільшуватися в розмірах. При цьому більшість 3 них морально та фізично застаріли і вичерпали свій ресурс заповнення відходами, що наразі $\epsilon$ великою екологічною загрозою довкіллю та суспільному життю [11].

Досвід зарубіжних країн свідчить, що при вирішенні питань щодо управління побутовими відходами, не слід підходити до них як до сміття, їх варто розглядати як вторинну сировину, здатну до рециклінгу та повторного використання.

Рециклінг відходів у зарубіжній практиці наразі визнано однією 3 досить прибуткових галузей економічної діяльності. В Україні ж перші спроби бізнес-рециклінгу завершились провалом, і насамперед, $з$ причини відсутності дієвих механізмів державного регулювання поводження 3 побутовими відходами. Тож, питання пошуку шляхів посилення дієвості механізмів державного регулювання поводження 3 побутовими відходами та можливості імплементації європейського досвіду у вітчизняну практику до тепер лишаються у центрі уваги та й надалі набуватимуть все більшої актуальності у зв'язку з ратифікацією положень Угоди про асоціацію між Україною та Європейським Союзом в частині охорони навколишнього середовища [22] як пріоритетного напряму співробітництва, а також у зв'язку з введенням 31 січня 2018 року заборони на захоронення неперероблених відходів, передбаченої ст. 32 Закону України «Про відходи» від 05.03.1998 р. за №187/98 (далі - Закон №187/98) [10] (зі змінами та доповненнями), яка чітко відповідає Директивам СС 1999/31/СС [28] та 2008/98/СС [29], що врегульовують питання поводження з відходами у країнах ЄС.

Однак перш ніж говорити про імплементацію європейського досвіду та можливі шляхи модифікації інструментарію державного регулювання поводження з побутовими відходами, варто чітко усвідомити зміст даного поняття, яке у законодавчих актах визнано як (табл.2): 


\section{Змістовна складова поняття «побутові відходи» відповідно до нормативно-правових актів}

\begin{tabular}{|c|c|}
\hline Aвт & Змістовна складова поняття \\
\hline $\begin{array}{l}\text { Закон України } \\
\text { «Про відходи» } \\
\text { від 05.03.1998 p. } \\
\text { №187/98 [10] }\end{array}$ & $\begin{array}{l}\text { побутові відходи - відходи, що утворюються в } \\
\text { процесі життя і діяльності людини в житлових та } \\
\text { нежитлових будинках (тверді, великогабаритні, ре- } \\
\text { монтні, рідкі, крім відходів, пов'язаних з виробни- } \\
\text { чою діяльністю підприємств) і не використовують- } \\
\text { ся за місцем їх накопичення }\end{array}$ \\
\hline $\begin{array}{l}\text { Проект Закону } \\
\text { «Про управління } \\
\text { відходами» від } \\
16.10 .2019 \text { №2207- } \\
1 \text { [12] }\end{array}$ & $\begin{array}{l}\text { муніципальні відходи: } \\
\text { змішані та роздільно зібрані відходи від домогоспо- } \\
\text { дарств, включаючи відходи паперу, картону, скла, } \\
\text { металів, пластику, деревини, текстилю, упаковки, } \\
\text { біовідходи, відходи електричного та електронного } \\
\text { обладнання, відпрацьовані батарейки, батареї та } \\
\text { акумулятори, а також великогабаритні відходи; } \\
\text { змішані та роздільно зібрані відходи з інших дже- } \\
\text { рел у разі, коли ці відходи подібні за своїм складом } \\
\text { до відходів домогосподарств; }\end{array}$ \\
\hline $\begin{array}{l}\text { Державний Кла- } \\
\text { сифікатор відходів } \\
\text { [2] }\end{array}$ & $\begin{array}{l}\text { побутові відходи - будь-які речовини та предмети, } \\
\text { утворювані у процесі виробництва та життєдіяль- } \\
\text { ності людини, що не мають свого подальшого при- } \\
\text { значення за місцем утворення і підлягають вида- } \\
\text { ленню чи переробці з метою забезпечення захисту } \\
\text { навколишнього середовища і здоров’я людей або з } \\
\text { метою повторного їх залучення у господарську ді- } \\
\text { яльність як матеріально-сировинних і енергетичних } \\
\text { ресурсів, а також послуги, пов'язані з відходами }\end{array}$ \\
\hline $\begin{array}{l}\text { ДСТУ 2195-99 } \\
\text { «Охорона приро- } \\
\text { ди. Поводження } 3 \\
\text { відходами» [4] }\end{array}$ & $\begin{array}{l}\text { побутові відходи - речовини, матеріали і предмети, } \\
\text { які утворюються в процесі людської діяльності, не } \\
\text { мають подальшого використання за місцем утво- } \\
\text { рення чи виявлення та яких їхній власник позбу- } \\
\text { вається, має намір або повинен позбутися шляхом } \\
\text { утилізації чи видалення }\end{array}$ \\
\hline
\end{tabular}


Продовження табл. 2

\begin{tabular}{|l|l|}
\hline Директива & $\begin{array}{l}\text { побутові відходи - це будь-яка речовина чи пред- } \\
\text { мет, яких власник позбувається, має намір чи зо- } \\
\text { бов’язаний позбутися }\end{array}$ \\
\hline Директива & $\begin{array}{l}\text { муніципальні відходи: } \\
\text { a) змішані відходи та окремо зібрані відходи до- } \\
\text { могосподарств, включаючи папір і картон, скло, } \\
\text { метали, пластик, біовідходи, деревину, текстиль, } \\
\text { упаковку, відпрацьоване електричне облад-нан- } \\
\text { ня, відпрацьовані батареї та акумулятори, а також } \\
\text { крупні відходи; } \\
\text { в) змішані відходи та окремо зібрані відходи з ін- } \\
\text { ших джерел, коли такі відходи подібні за характе- } \\
\text { ром та складом до відходів домогосподарств }\end{array}$ \\
\hline
\end{tabular}

Таким чином, побутові відходи включають відходи, що утворюються в процесі життя і діяльності людини в житлових та нежитлових будинках, а також відходи від утримання парків та садів, а також відходи 3 ринку та послуги з очищення вулиць, такі як вміст контейнерів для сміття та відходів, за винятком таких матеріалів, як пісок, скеля, бруд або пил.

А отже, на законодавчому рівні побутові відходи в Україні розглядаються як сміття, в той час як міжнародними стандартами та Директивами СС їх рекомендовано розглядами як вторинні ресурси, тобто як ресурси здатні до повторного використання. Тож, зі стратегічною спрямованістю України на інтеграцію в СС та входженням в його правове поле, а також набуттям зобов'язань 3 екологізації економіки найбільш повноцінним вважаємо трактування даного поняття за відновлювальним підходом як відходів, що утворюються в процесі життя і діяльності людини, які завдяки рециклінгу (перетворення у вторинні ресурси) здатні до забезпечення генерування економічного зростання, ресурсоощадності, енергоефективності та зниження техногенного навантаження на довкілля. Звертаємо увагу, що лише завдяки рециклінгу (перетворення у вторинні ресурси) відходи набувають своєї значимості як ресурси. А отже, ототожнення 
понять «відходи» та «вторинні ресурси», ані в науці, ані в практиці недопустиме.

Відмінні риси відходів від вторинних ресурсів подано на рис. 1:

\begin{tabular}{|c|c|}
\hline Загальна сукупність відходів & Частка відходів, придатна до переробки \\
\hline $\begin{array}{l}\text { Відокремлені від кінцевого використання } \\
\text { речовин та матеріалів }\end{array}$ & $\begin{array}{l}\text { Пов'язані } 3 \text { кінцевим } \\
\text { речовин, матеріалів та предметівистанням }\end{array}$ \\
\hline $\begin{array}{l}\text { Продовжують своє існування до утилізації } \\
\text { чи до підготовки до переробки }\end{array}$ & $\begin{array}{l}\text { Починають своє існування } 3 \text { переробкою } \\
\text { та уилізацією }\end{array}$ \\
\hline $\begin{array}{l}\text { Завдяки переробці перетворюються } \\
\text { вторинні ресурси }\end{array}$ & $\begin{array}{l}\text { Завдяки переробці перетворюються } \\
\text { новий продукт }\end{array}$ \\
\hline $\begin{array}{l}\text { Створюють екологічні загрози навколиш- } \\
\text { ньому середовищу та економічні загрози } \\
\text { суб'єктам господарювання }\end{array}$ & $\begin{array}{l}\text { Після переробки наділяються новими } \\
\text { споживчими властивостями та забезпе- } \\
\text { чують отримання інвайронментального } \\
\text { ефекту }\end{array}$ \\
\hline Відходи & Вторинні ресурси \\
\hline
\end{tabular}

Рис. 1. Порівняльний аналіз відмінних риси відходів та вторинних ресурсів [6]

Відповідальність за поводження 3 побутовими відходами (під яким згідно ст. 1 Закону 187/98 розуміється надання послуг з вивезення, перероблення та захоронення побутових відходів, що надаються в населеному пункті згідно з правилами благоустрою територіï населеного пункту, розробленими з урахуванням схеми санітарного очищення населеного пункту та затвердженими органом місцевого самоврядування [10]), практично повністю покладається на органи місцевого самоврядування (об’єднанні територіальні громади), що цілком відповідає нормам, викладеним у Директиві ЄС 2018/851 від 30 травня 2018 р. [30], яка доповнює Директиву 2008/98/ЄС про відходи [29].

Наразі поводження 3 побутовими відходами регулюється законодавчими актами, перелік яких подано в табл. 3, фундаментальним серед яких залишає-ться Закон 187/98 (зі змінами та доповненнями). 
Таблиця 3

\section{Правові аспекти регулювання відносин у сфері поводження з побутовими відходами}

\begin{tabular}{|c|c|}
\hline Законодавчий акт & Змістовна складова \\
\hline $\begin{array}{l}\text { Закон України «Про від- } \\
\text { ходи» від 05.03.1998 p. } \\
\text { №187/98 [10] }\end{array}$ & $\begin{array}{l}\text { передбачено, що поводження з побутовими } \\
\text { відхо-дами розуміється надання послуг з ви- } \\
\text { везення, перероблення та захоронення побу- } \\
\text { тових відходів, що надаються в населеному } \\
\text { пункті згідно з правилами благоустрою те- } \\
\text { риторії населеного пункту, розроблю-ними } \\
\text { з урахуванням схеми санітарного очищення } \\
\text { населеного пункту та затвердженими орга- } \\
\text { ном місцевого самоврядування. }\end{array}$ \\
\hline $\begin{array}{l}\text { Про житлово-комунальні } \\
\text { послуги від 09.11.2017 p. № } \\
\text { 2189-VIII [17] }\end{array}$ & $\begin{array}{l}\text { передбачено передання повноважень } 3 \\
\text { питань перероблення та захоронення по- } \\
\text { бутових відходів, а також встановлення } \\
\text { тарифів в цілому на поводження } 3 \text { ТПВ } \\
\text { органам місцевого самоврядування }\end{array}$ \\
\hline $\begin{array}{l}\text { Про упаковку та відходи } \\
\text { упаковки від } 14.01 .15 \text { р. № } \\
1742[18]\end{array}$ & $\begin{array}{l}\text { передбачено демонополізаціію ринку по- } \\
\text { слуг з переробки та захоронення побуто- } \\
\text { вих відходів шляхом передачі повнова- } \\
\text { жень ОМС та встановлення економічно } \\
\text { обгрунтованих тарифів на ці послуги }\end{array}$ \\
\hline $\begin{array}{l}\text { Про внесення змін до } \\
\text { деяких законодавчих актів } \\
\text { України у сфері поводження } \\
\text { 3 побутовими відхода-ми від } \\
\text { 05.02.2016 р. № } 4028 \text { [19] }\end{array}$ & $\begin{array}{l}\text { передбачено механізм налагодження ефек- } \\
\text { тивної системи збору використаної тари та } \\
\text { упаковки, що є у складі побутових відходів, } \\
\text { виконання європейського принципу «роз- } \\
\text { ширеної відповідальності виробника» }\end{array}$ \\
\hline $\begin{array}{l}\text { Про внесення змін до По- } \\
\text { даткового кодексу України } \\
\text { (щодо включення податку за } \\
\text { виробництво й імпорт упа- } \\
\text { ковки та товарів в упаковці } \\
\text { до екологічного податку) від } \\
21.10 .2015 \text { р. № } 3199-1 \text { [20] }\end{array}$ & $\begin{array}{l}\text { передбачено операції з виробництва й } \\
\text { імпорту ПЕТ-тари, упаковок та товарів в } \\
\text { упаковці оподаткувати екологічним по- } \\
\text { датком і спрямувати його виключно на } \\
\text { оплату послуг з переробки побутових від- } \\
\text { ходів }\end{array}$ \\
\hline
\end{tabular}


Таблиця 4

\section{Правові аспекти стимулювання ефективного поводження з побутовими відходами [6]}

\begin{tabular}{|c|c|c|}
\hline Законодавчі акти & Основний зміст & $\begin{array}{r}\text { Включено } \\
\text { до порядку } \\
\text { денного ВР } \\
\end{array}$ \\
\hline $\begin{array}{l}\text { Законопроект «Про } \\
\text { внесення змін до } \\
\text { дея-ких законів } \\
\text { України щодо сти- } \\
\text { мулювання викори- } \\
\text { стання побуто-вих } \\
\text { відходів як аль- } \\
\text { тер-нативного дже- } \\
\text { рела енергії №4835- } \\
\text { д від } 31.07 .2017 \text { p. } \\
\text { [13] }\end{array}$ & $\begin{array}{l}\text { Визначено комплексне врегулюван- } \\
\text { ня питання поводження з побутови- } \\
\text { ми відходами, удоско-налення ме- } \\
\text { ханізмів державного регулювання у } \\
\text { сфері поводження з побутовими від- } \\
\text { ходами на основі директиви 2008/98/ } \\
\text { СС про відходи, створення сприят- } \\
\text { ливих законодавчих умов для залу- } \\
\text { чення інвестицій в енергетичну га- } \\
\text { лузь та стимулювання виробництва } \\
\text { електроенергії і тепла шляхом утилі- } \\
\text { зації відходів завдяки поширенню на } \\
\text { цей вид електроенергії «зеленого» } \\
\text { тарифу. }\end{array}$ & 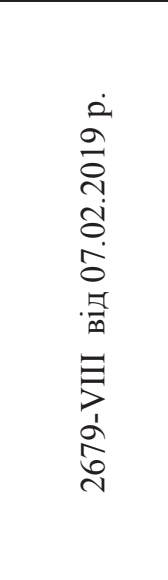 \\
\hline $\begin{array}{l}\text { Законопроект «Про } \\
\text { вне сення змін до } \\
\text { Податко-вого кодек- } \\
\text { су України (щодо } \\
\text { оподаткування роз- } \\
\text { міщення побутових } \\
\text { відходів) №4836 від } \\
\text { 16.06.2016 p. [14] }\end{array}$ & $\begin{array}{l}\text { Визначено ставки екологічного по- } \\
\text { датку за: } \\
\text { - розміщення малонебезпечних по- } \\
\text { бутових відходів та ін. малонебез- } \\
\text { печних відходів; } \\
\text { - за виробництво й імпорт упаковки } \\
\text { та товарів в упаковці. } \\
\text { Передбачено щорічну індексацію } \\
\text { ставки екологічного податку за ви- } \\
\text { робництво й імпорт упаковки та то- } \\
\text { варів в упаковці }\end{array}$ & 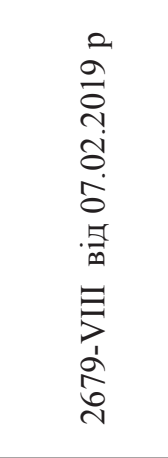 \\
\hline $\begin{array}{l}\text { Законопроект «Про } \\
\text { управління відхода- } \\
\text { ми» (незареєстрова- } \\
\text { ний) [12] }\end{array}$ & $\begin{array}{l}\text { Визначено ієрархію управління } \\
\text { відходами та розширеної відпові- } \\
\text { дальності виробників. Передбачено } \\
\text { впровадження інформаційної систе- } \\
\text { ми управління відходами. }\end{array}$ & 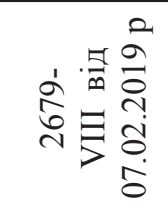 \\
\hline
\end{tabular}


Продовження табл. 4

\begin{tabular}{|c|c|c|}
\hline $\begin{array}{l}\text { Законопроект «Про } \\
\text { внесення змін до } \\
\text { Бюджетного кодек- } \\
\text { су України (щодо } \\
\text { використання дея- } \\
\text { ких видів екологіч- } \\
\text { ного податку)» № } \\
4837 \text { від 16.06.2016 } \\
\text { р. [15] }\end{array}$ & $\begin{array}{l}\text { Визначено порядок перерозподілу } \\
\text { між доходами загального та спе- } \\
\text { ціального фонду Державного бю- } \\
\text { джету, а також спеціального фонду } \\
\text { місцевих бюджетів екологічного по- } \\
\text { датку, що справляється за виробни- } \\
\text { цтво й імпорт упаковки та товарів в } \\
\text { упаковці, а також за розміщення ма- } \\
\text { лонебезпечних побутових відходів. } \\
\text { Передбачено трансферти з Держав- } \\
\text { ного бюджету місцевим бюджетам у } \\
\text { вигляді субвенцій. }\end{array}$ & 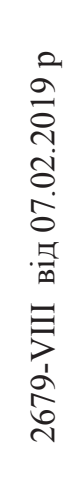 \\
\hline $\begin{array}{l}\text { Законопроект «Про } \\
\text { про систему зби- } \\
\text { рання та утиліза- } \\
\text { ції використаної } \\
\text { тари» №5614 від } \\
\text { 28.12.2016 p. [16] }\end{array}$ & $\begin{array}{l}\text { Здійснено приписи, за якими має } \\
\text { впровадитися функціонування за- } \\
\text { ставних цін на тару, створення та } \\
\text { функціонування депозитної системи } \\
\text { тари, яка має включати операторів } \\
\text { депозитної системи, точки збору, } \\
\text { споживачів та механізм повернення } \\
\text { заставних коштів споживачу }\end{array}$ & 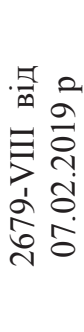 \\
\hline
\end{tabular}

Однак, на жаль, можливостей повноцінного дотримання Закону №187/98 [10] наразі недостатньо, оскільки інфраструктура для збирання, первинного та вторинного сортування, для перероблення і безпечного захоронення цих відходів в Україні, на відміну від країн ЄС, перебуває лише в зародковому стані Тож, норма Закону №187/98 щодо переробленя відходів до тепер носить лише декларативний характер.

Управління поводженням 3 побутовими відходами має відбуватися як на всіх рівнях державного управління, так і на рівні територіальної громади, адже саме децентралізація влади дає можливість вирішення більшості питань, що виникають на рівні громади, та $є$ найбільш наближеною до потреб громадян [5, с.128]. Тому підтримуємо думку науковців, які стверджують, що одним із пріоритетних завдань регіонального розвитку є саме підвищення ефективності ви- 
користання природно-економічного потенціалу території у тому числі на основі капіталізації відходів завдяки їх рециклінгу [8, с. 89].

Однак, на жаль, правові аспекти стимулювання до ефективного поводження 3 побутовими відходами наразі лишаються дискусійними, оскільки передбачаються законопроектами, які до тепер перебувають на розгляді уряду (табл. 4):

За своїм змістом кожен $з$ поданих в табл. 3 законопроектів відповідають принципам поводження з відходами, визначеним Національною стратегією управління відходами в Україні до 2030 року (рис. 2):

iєрархії поводження з відходами, який передбачає дії стосовно поводження 3
відходами у такій послідовності: запобігання утворенню відходів, підготовку до
повторного використання без попередньої обробки, перероблення відходів, інші види
утилізації у тому числі використання відходів як вторинних енергетичних ресурсів,
видалення (захоронення) лише у разі відсутності можливості виконати попередні
ступені ієрархії

Pис. 2. Принциии поводження з відходами за Національною стратегією управління відходами в Украӥні до 2030 року [7]

Однак до тепер лишаються не затвердженими, що суттєво ускладнює адміністрування територіальними громадами поводження 3 відходами, налагодження їх взаємодії з операторами та іншими 
учасниками процесу рециклінгу побутових відходів, яка б забезпечила розподіл відповідальності між державними та приватними суб'єктами. Задля переконання у необхідності в даній взаємодії, зупинимось на вивченні регулювання поводження з побутовими відходами у Полтавському субрегіоні.

Згідно Субрегіональної стратегії поводження з відходами [21] у Полтавській області (далі - Субрегіональна стратегія), розробленій європейськими експертами за підтримки Deutsche Gesellschaft für Internationale Zusammenarbeit (GIZ) $\mathrm{GmbH}$ у рамках міжнародного проекту «Реформа управління на сході України» (PN 112129.2-001.00) з метою модифікації системи управління побутовими відходами у Полтавській області виокремлено п’яти субрегіонів: Полтавського, Кременчуцького, Пирятинського, Хороль-ського та Гадяцького субрегіонів [21].

Зокрема, Полтавський субрегіон відповідно до Меморандуму про співробітництво з реалізації субрегіональної стратегії поводження з ТПВ від 7 жовтня 2016 року поєднує п’ять адміністративних районів Полтавської області: Полтавського, Новосанжарського, Карлівського, Машівського, Чутівського та обласний центр м. Полтаву, а отже, і відповідні територіальні громади.

За Субрегіональною стратегією [21] передбачено будівництво сучасного полігону побутових відходів та 5 сортувальних станцій, на розміщення яких за розпорядженням голови Полтавської райдержадміністрації від 09.11.2017 року «Про розробку детального плану» прийнято рішення щодо відведення під будівництво території, розташованої за межами населених пунктів (яка на теперішній час перебуває у постійному користуванні ДП «Полтавське лісове господарство»), а саме в кварталі 121 Чалівського лісництва в адміністративних межах Микільської сільської ради Полтавського району [11].

Нині оператором поводження $з$ побутовими відходами по Полтавському субрегіоні виступає Полтавське-КАТП-1628, яке належить до комунальної власності Полтавської міської громади. Сдиним методом поводження 3 побутовими відходами згідно Статуту Полтавське-КАТП-1628 є ліквідаційний (збір та вивезення сміття на звалище) [11]. 
Переконані, що будівництво перелічених об'єктів лише частково вирішить екологічні проблеми Полтавського субрегіону, питання ж капіталізації побутових відходів знову ж поза увагою. Змінити ситуацію щодо поводження з побутовими відходами та їх капіталізації можливо за умови вжиття заходів щодо розвитку рециклінгу, необхідність у запровадженні якого обгрунтовується, насамперед, обсягами утворення відходів.

Оскільки ані кількісного, ані якісного обліку побутових відходів по Полтавському субрегіоні не ведеться жодним 3 органів, то їх обсяги визначаються розрахунковим шляхом, виходячи з чисельності населення та норм утворення побутових відходів, визначених відповідно до Правил визначення норм надання послуг з вивезення побутових відходів, затверджених Наказом Міністерства 3 питань ЖКГ України від 30.07.2010 р. за №259 (далі - Наказ №259) [9].

Протягом останніх років, не дивлячись на незначний демографічний спад чисельності населення, по Полтавському субрегіоні чіткої тенденції змін обсягів побутових відходів, як свідчать дані табл. 5 не сформовано. Проте на перспективу очікується, що зі зростанням потреб населення та рівнем його платоспроможності обсяги побутових відходів невпинно зростатимуть, що $є$ абсолютно природнім.

Таблиця 5

Демографічні зміни чисельності населення Полтавського субрегіону протягом 2008-2017 рр., тис. осіб [23,24,25,26, 27]

\begin{tabular}{|c|c|c|c|c|c|c|}
\hline \multirow{2}{*}{ 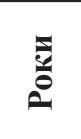 } & \multicolumn{6}{|c|}{ Райони } \\
\hline & $\begin{array}{c}\text { Карлів- } \\
\text { ський }\end{array}$ & $\begin{array}{c}\text { Машів- } \\
\text { ський }\end{array}$ & $\begin{array}{l}\text { Новасан- } \\
\text { жарський }\end{array}$ & $\begin{array}{c}\text { Полтав- } \\
\text { ський }\end{array}$ & $\begin{array}{c}\text { м. Пол- } \\
\text { тава }\end{array}$ & $\begin{array}{l}\text { Чутків- } \\
\text { ський }\end{array}$ \\
\hline 2014 & 34,4 & 19,8 & 35,0 & 67,0 & 295,5 & 23,3 \\
\hline 2015 & 34,2 & 19,7 & 34,7 & 67,1 & 294,5 & 23,0 \\
\hline 2016 & 33,9 & 19,6 & 34,4 & 67,4 & 285,9 & 23,0 \\
\hline 2017 & 33,6 & 19,4 & 34,0 & 67,5 & 283,7 & 22,8 \\
\hline 2018 & 33,2 & 19,1 & 33,5 & 68,0 & 281,9 & 22,5 \\
\hline
\end{tabular}


Відповідно до даних табл. 5 найбільший демографічний спад чисельності населення спостерігається по м. Полтава. Протягом періоду, що вивчався чисельність населення міста зменшилась майже на 15 тис. осіб, що насамперед, пов'язано із низьким рівнем народжуваності, високими показниками смертності та величезним відтоком молоді до більш заможних держав Західної Європи.

Ситуація щодо змін норм утворення побутових відходів, затверджених рішенням органів місцевого самоврядування, абсолютно протилежна змінам чисельності населення Полтавського субрегіону (табл. 6):

Таблиця 6

Динаміка норм утворення побутових відходів за видами житла по Полтавському субрегіоні протягом 2007-2018 рр. [11]

\begin{tabular}{|c|c|c|c|c|c|}
\hline \multirow{2}{*}{$\begin{array}{c}\text { Найменування об'єкта утво- } \\
\text { рення побутових відходів }\end{array}$} & \multicolumn{5}{|c|}{ Роки } \\
\hline & 2014 & 2015 & 2016 & 2017 & 2018 \\
\hline $\begin{array}{l}\text { Житлові будинки багатоквар- } \\
\text { тирні: } \\
\text { - висотні (більше 5-и повер- } \\
\text { хів), упорядковані (газ, цен- } \\
\text { тральне опалення, водопровід, } \\
\text { каналізація), із сміттєпрово- } \\
\text { дами, м3 }\end{array}$ & 1,70 & 1,70 & 1,70 & 1,76 & 1,81 \\
\hline $\begin{array}{l}\text { - малоповерхові (до 5-и повер- } \\
\text { хів), упорядковані (газ, цен- } \\
\text { тральне опалення, водопровід, } \\
\text { каналізація), без сміттєпрово- } \\
\text { дів, м3 }\end{array}$ & 1,84 & 1,84 & 1,84 & 1,91 & 1,97 \\
\hline $\begin{array}{l}\text { Житлові будинки індивіду- } \\
\text { альної забудови (приватного } \\
\text { сектору, котеджні) упорядко- } \\
\text { вані (газ, водопровід, газове } \\
\text { чи рідинне опалення), м3 }\end{array}$ & 1,96 & 1,96 & 1,96 & 2,31 & 2,54 \\
\hline
\end{tabular}


Відповідно до даних табл.6 протягом 2014-2018 років норми утворення побутових відходів для мешканців висотних та малоповерхових будинків зросли майже на 10\%, в той час, як для мешканців житлових будинків приватного сектору - практично на 30\%.

При розрахунку очікуваних обсягів побутових відходів не залишився поза увагою і відсоток охоплення населення наданням послуг 3 поводження $з$ побутовими відходами, який станом на кінець 2018 року характеризується даними, поданим на рис.3:

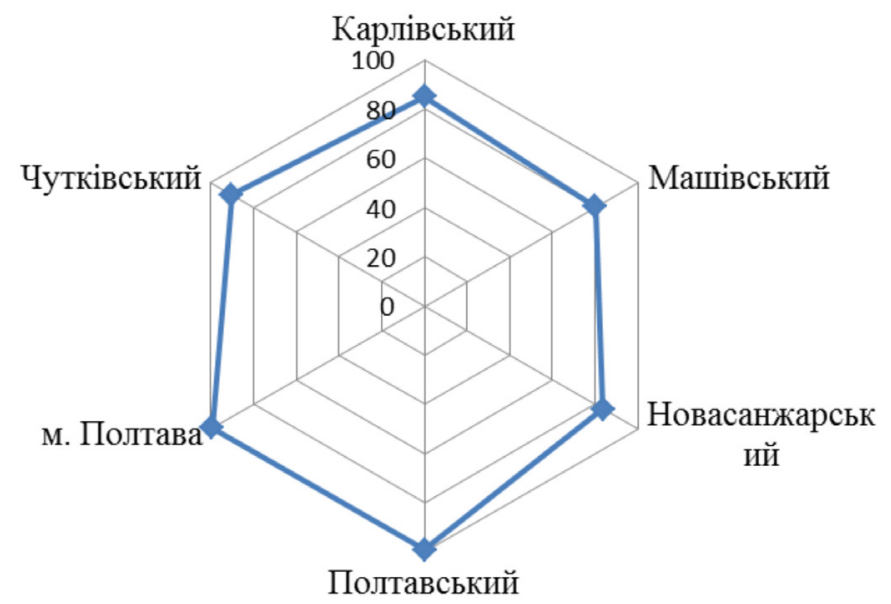

Pис. 3. Відсоток охоплення населення наданням послуг з поводження з відходами [11]

Відповідно до даних рис.4 найвищий відсоток охоплення населення наданням послуг 3 поводження 3 побутовими відходами спостерігається в Полтавському районі та м. Полтава, та найнижчий у Машівському районі - ледве перевищує 80\% населення, проживаючого у даному районі.

3 урахуванням всіх перелічених факторів розрахункові обсяги побутових відходів протягом 2014-2018 рр. становили (табл.7): 
Динаміка розрахункових показників утворення відходів Полтавського субрегіону протягом 2008-2017 pp., т [3]

\begin{tabular}{|l|l|l|l|l|l|l|}
\hline \multirow{2}{*}{ Роки } & \multicolumn{6}{|c|}{ Райони } \\
\cline { 2 - 7 } & $\begin{array}{c}\text { Карлів- } \\
\text { ський }\end{array}$ & $\begin{array}{c}\text { Машів- } \\
\text { ський }\end{array}$ & $\begin{array}{c}\text { Нова- } \\
\text { санжар- } \\
\text { ський }\end{array}$ & $\begin{array}{c}\text { Полтав- } \\
\text { ський }\end{array}$ & $\begin{array}{c}\text { м. Пол- } \\
\text { тава }\end{array}$ & $\begin{array}{c}\text { Чутків- } \\
\text { ський }\end{array}$ \\
\hline 2014 & 193278,5 & 49673,1 & 467898,2 & 76890,3 & 158748,0 & 39285,4 \\
\hline 2015 & 211344,2 & 47341,7 & 520945,7 & 80367,4 & 169783,2 & 43572,1 \\
\hline 2016 & 232451,7 & 53611,7 & 566411,3 & 84919,2 & 161260,8 & 42169,8 \\
\hline 2017 & 160159,2 & 32971,2 & 437269,5 & 60292,6 & 159164,5 & 33693,7 \\
\hline 2018 & 191285,1 & 46407,7 & 442469,1 & 68046,5 & 187266,4 & 36755,8 \\
\hline
\end{tabular}

При цьому стан полігонів та сміттєзвалищ Полтавського субрегіону залишається вкрай незадовільним - зі 115 полігонів та сміттєзвалищ, розміщених на території Полтавського субрегіону, лише 18 можуть бути залишені у тимчасові експлуатації, решта, а саме 97 - рекомендується вивести із експлуатації через значне перевантаження, що ще раз підкреслює необхідність в екологізації території та розвитку рециклінгу відходів.

Звісно прийняття рішення щодо розвитку рециклінгу визначається не лише обсягами побутових відходів, а й їх морфологічним складом, завдяки якому саме і встановлюється їх ресурсний потенціал. Так, у рамках проекту GIZ для умов Полтавської області було визначено склад твердих побутових відходів за чотирма найбільш характерними категоріями житла (табл. 8): 


\section{Склад ТПВ згідно категорій житла, \% [11]}

\begin{tabular}{|c|c|c|c|c|c|c|}
\hline 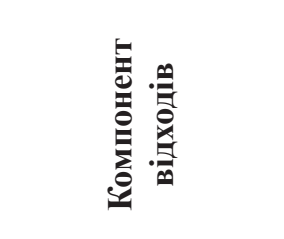 & 䖯 & 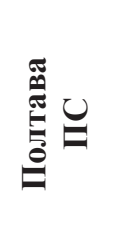 & 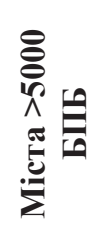 & 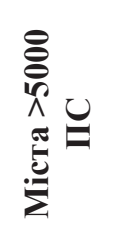 & 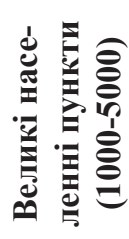 & 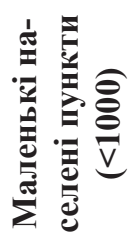 \\
\hline Органічні відходи & 43,3 & 37,1 & 29 & 19 & 14 & 19.3 \\
\hline Папір, картон & 9 & 7 & 9 & 7 & 8 & 1,4 \\
\hline Пластик & 12 & 13 & 13 & 13 & 13 & 11 \\
\hline Скло & 11 & 18 & 15 & 21 & 17 & 24 \\
\hline Метал & 1,1 & 1,2 & 0,8 & 1,1 & 2 & 3,8 \\
\hline Інші & 23,6 & 23,7 & 33,2 & 38,9 & 46 & 40,5 \\
\hline Разом & 100.00 & 100.00 & 100.00 & 100.00 & 100.00 & 100.00 \\
\hline
\end{tabular}

Однак дана структура змінюється не лише з часом та сезонністю, а й залежно від того, на якій конкретній території утворюються відходи (міська чи сільська місцевість). А отже, для встановлення обсягів цінних компонентів у побутових відходах враховано і розподіл населення Полтавського субрегіону за місцем проживання (табл. 9).

Таблиця 9

Динаміка розподілу населення Полтавського субрегіону за місцем проживання протягом 2007-2018 рр., тис. осіб $[23,24,25,26,27]$

\begin{tabular}{|l|c|c|c|c|c|}
\hline \multirow{2}{*}{\multicolumn{1}{|c|}{ Райони }} & \multicolumn{5}{|c|}{ Роки } \\
\cline { 2 - 6 } & $\mathbf{2 0 1 4}$ & $\mathbf{2 0 1 5}$ & $\mathbf{2 0 1 6}$ & $\mathbf{2 0 1 7}$ & $\mathbf{2 0 1 8}$ \\
\hline Карпівський, всього & 34,4 & 34,2 & 33,9 & 33,6 & 33,2 \\
\hline в т.ч. міське & 15,0 & 15,0 & 15,2 & 15,5 & 15,9 \\
\hline сільське & 19,4 & 19,2 & 18,7 & 18,1 & 17,3 \\
\hline Машівський, всього & 19,8 & 19,7 & 19,6 & 19,4 & 19,1 \\
\hline в т.ч. міське & 3,8 & 3,8 & 4,1 & 4,3 & 4,6 \\
\hline
\end{tabular}


Продовження табл. 9

\begin{tabular}{|l|c|c|c|c|c|}
\hline сільське & 16,0 & 15,9 & 15,5 & 15,1 & 14,5 \\
\hline Новасанжарський, всього & 35,0 & 34,7 & 34,4 & 33,9 & 33,5 \\
\hline в т.ч. міське & 8,4 & 8,4 & 8,8 & 9,4 & 10,1 \\
\hline сільське & 26,6 & 26,3 & 25,6 & 24,5 & 23,4 \\
\hline Полтавський, всього & 67,0 & 67,1 & 67,4 & 67,5 & 68,0 \\
\hline в т.ч. міське & $\mathrm{x}$ & $\mathrm{x}$ & $\mathrm{x}$ & $\mathrm{x}$ & $\mathrm{x}$ \\
\hline сільське & 67,0 & 67,1 & 67,4 & 67,5 & 68,0 \\
\hline м. Полтава, всього & 295,5 & 294,5 & 285,9 & 283,7 & 281,9 \\
\hline в Т.ч. міське & 295,5 & 294,5 & 285,9 & 22,8 & 281,9 \\
\hline сільське & $\mathrm{x}$ & $\mathrm{x}$ & $\mathrm{x}$ & $\mathrm{x}$ & $\mathrm{x}$ \\
\hline Чутівський, всього & 23,3 & 23,0 & 23,0 & 22,8 & 22,5 \\
\hline в т.ч. міське & 9,6 & 9,5 & 9,9 & 10,5 & 11,2 \\
\hline сільське & 13,7 & 13,5 & 13,1 & 12,3 & 11,3 \\
\hline
\end{tabular}

Таким чином, обсяги ресурсоцінних компонентів (потенціал вторинної сировини) по Полтавському субрегіону у звітному році склали (табл. 10), що ще раз доводить необхідність перетворення сектора утилізації та повторної переробки відходів в прибутковий сектор економіки.

Таблиця 10

Обсяги ресурсоцінних компонентів (потенціал вторинної сировини), м3/рік [11]

\begin{tabular}{|c|c|c|c|c|c|c|}
\hline \multirow[b]{2}{*}{ Роки } & \multicolumn{5}{|c|}{ Райони } & \multirow[b]{2}{*}{ Разом } \\
\hline & $\begin{array}{c}\text { Карлів- } \\
\text { ський }\end{array}$ & $\begin{array}{c}\text { Машів- } \\
\text { ський }\end{array}$ & $\begin{array}{c}\text { Нова- } \\
\text { санжар- } \\
\text { ський }\end{array}$ & $\begin{array}{c}\text { Полтав- } \\
\text { ський }\end{array}$ & $\begin{array}{l}\text { Чутків- } \\
\text { ський }\end{array}$ & \\
\hline $\begin{array}{l}\text { Загальна } \\
\text { кількість } \\
\text { утворен- } \\
\text { ня по- } \\
\text { бутових } \\
\text { відходів, } \\
\text { м3/рік }\end{array}$ & 68827,0 & 23032,0 & 52142,0 & 686946,5 & 53224,0 & 884171,5 \\
\hline
\end{tabular}


Продовження табл. 10

\begin{tabular}{|l|c|c|c|c|c|c|}
\hline $\begin{array}{l}\text { Органічні } \\
\text { відходи }\end{array}$ & 13972,0 & 4675,0 & 10585,0 & 279506,6 & 10804,0 & 319542,6 \\
\hline $\begin{array}{l}\text { Папір, } \\
\text { картон }\end{array}$ & 4371,0 & 1463,0 & 3311,0 & 55623,2 & 3380,0 & 68148,2 \\
\hline Пластик & 7915,0 & 2649,0 & 5996,0 & 69529,0 & 6121,0 & 92210 \\
\hline Скло & 13249,0 & 4434,0 & 10037,0 & 97340,6 & 10246,0 & 135306,6 \\
\hline Метал & 1328,0 & 445,0 & 1006,0 & 7648,2 & 1027,0 & 11454,2 \\
\hline Текстиль & 2581,0 & 864,0 & 1955,0 & 22249,3 & 1996,0 & 29645,3 \\
\hline Дерево & 964,0 & 322,0 & 730,0 & 4171,7 & 745,0 & 6932,7 \\
\hline $\begin{array}{l}\text { Небез- } \\
\text { печні }\end{array}$ & 447,0 & 150,0 & 339,0 & 4867,0 & 346,0 & 6149 \\
\hline $\begin{array}{l}\text { Кістки, } \\
\text { шкіра, } \\
\text { гума }\end{array}$ & 2464,0 & 825,0 & 1867,0 & 6952,9 & 1905,0 & 14013,9 \\
\hline Мінерали & 21543,0 & 7209,0 & 16320,0 & 139058,0 & 16659,0 & 200789 \\
\hline
\end{tabular}

Отже, приходимо до висновку, що рециклінг як складова системи вторинного ресурсокористування має розглядатись територіальними громадами в економічній площині, тобто бути об'єктом концептуального розвитку територій. А отже, кожною з територіальних громад має бути сформована Концепція взаємодії об'єднаних територіальних громад з учасниками процесу рециклінгу побутових відходів (далі - Концепція) (рис.5), головною ціллю якою має стати перетворення сектора утилізації та повторної переробки відходів на прибутковий сегмент економіки і, відповідно, ємнісну сферу «зелених» робочих місць, яка забезпечуватиме надання високоякісних послуг з вивезення, перероблення та захоронення побутових відходів, що надаються в населеному пункті згідно з правилами благоустрою території населеного пункту, розробленими з урахуванням схеми санітарного очищення населеного пункту та затвердженими органом місцевого самоврядування.

При формуванні Концепції територіальними громадами мають бути чітко визначені імперативи, базові принципи та підходи, іiі структурні положення та важелі реалізації. 
«Public Administration and Regional Development»

https://pard.mk.ua/index.php/journal

\begin{tabular}{|c||c|c|c|}
\hline \multicolumn{3}{|c|}{ Імперативи } \\
\hline $\begin{array}{c}\text { Рециклінг } \\
\text { відходів }\end{array}$ & $\begin{array}{c}\text { Ресурсозбере } \\
\text { ження }\end{array}$ & $\begin{array}{c}\text { Енергозбереження та } \\
\text { енергоефективність }\end{array}$ & $\begin{array}{c}\text { Зниження техногенного } \\
\text { навантаження на довкілля }\end{array}$ \\
\hline
\end{tabular}

Головна ціль - перетворення сектора утилізації та повторної переробки відходів на прибутковий сегмент економіки i, відповідно, ємнісну сферу «зелених» робочих місць, яка забезпечуватиме надання високоякісних послуг

\begin{tabular}{|c|c|c|c|c|c|c|c|}
\hline \multirow{3}{*}{ 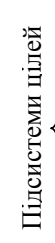 } & \multicolumn{7}{|c|}{$\begin{array}{l}\text { Економічна - забезпечення ефективного управління поводженням } 3 \text { побутовими відхода- } \\
\text { ми, спрямованого на екологізацію економіки та розвиток територій, засноване на взаємо- } \\
\text { дії територіальних громад з учасниками процесу рециклінгу та розподілі відповідальності }\end{array}$} \\
\hline & \multicolumn{7}{|c|}{$\begin{array}{l}\text { Соціальна - створення додаткових робочих місць, поліпшення умов праці, зниження } \\
\text { рівня захворюваності, а також поліпшення якості життя населення територіальної } \\
\text { громади }\end{array}$} \\
\hline & \multicolumn{7}{|c|}{$\begin{array}{l}\text { Екологічна - максимізації інвайроментальної (екологічної) ефективності рециклінгу } \\
\text { побутових відходів та мінімізації термінів її досягнення }\end{array}$} \\
\hline \multicolumn{3}{|c|}{ 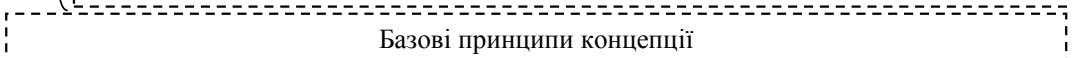 } & \multicolumn{5}{|c|}{ побутових відходів та мінімізації термінів ії досягнення } \\
\hline \multicolumn{2}{|c|}{$\begin{array}{c}\text { ієрархії } \\
\text { поводження } \\
\text { 3 відходами }\end{array}$} & $\begin{array}{c}\text { переходу до } \\
\text { економіки замк- } \\
\text { неного циклу }\end{array}$ & $\begin{array}{l}\text { наближе- } \\
\text { ності }\end{array}$ & $\begin{array}{l}\text { попе } \\
\text { женс }\end{array}$ & & $\begin{array}{c}\text { спільної } \\
\text { відповідаль } \\
\text { ності }\end{array}$ & $\begin{array}{c}\text { розширеної } \\
\text { відповідально- } \\
\text { сті виробника }\end{array}$ \\
\hline \multicolumn{8}{|c|}{ Підходи } \\
\hline \multicolumn{2}{|c|}{$\begin{array}{l}\text { взаємодії } \\
\text { учасників }\end{array}$} & $\begin{array}{l}\text { збалансованості } \\
\text { інтересів учасників }\end{array}$ & \multicolumn{2}{|c|}{$\begin{array}{l}\text { розподілу } \\
\text { відповідальност }\end{array}$} & \multicolumn{2}{|c|}{$\begin{array}{c}\text { екологізації } \\
\text { територій }\end{array}$} & $\begin{array}{c}\text { ресурсо- та } \\
\text { енергозбереження }\end{array}$ \\
\hline
\end{tabular}

Структурні положення концепції
1

- забезпечення системи роздільного збору відходів від населення та сортування на спеціальних лініях завдяки залученню коштів інвесторів, донорів та фондів 3 охорони довкілля

- забезпечення рециклінгу відходів, здатних до генерування економічного зростання, ресурсоощадності, енергоефективності та зниження техногенного навантаження на довкілля

- забезпечення збалансування інтересів учасників процесу рециклінгу у максимізації інварроментальної ефективності та мінімізації термінів її досягнення

- забезпечення створення ємнісної сфери «зелених» робочих місць

- забезпечення інформування населення про проблему побутових відходів та відповідальність кожного мешканця за чистоту, підвищення рівня виховання та свідомості населення

Важелі реалізації концепції

Puc. 5. Концепиія взаємодії об'єднаних територіальних громад з учасниками процесу рециклінгу побутових відходів [авторське бачення] 
Сформована у такий спосіб Концепція забезпечить взаємодію територіальних громад з учасниками процесу рециклінгу побутових відходів, а також сприятиме екологізації економіки та перетворенню сектора утилізації й повторної переробки побутових відходів на іiі прибутковий сегмент.

Висновки. Підводячи підсумок вищевикладеному, приходимо до висновку, що активізації переходу від полігонного захоронення побутових відходів до їх промислової переробки обумовлює необхідність розробки концептуальних підходів до формування дійових механізмів державного регулювання ефективного поводження з побутовими відходами, які забезпечать перетворення сектора утилізації та повторної переробки відходів на прибутковий сегмент економіки.

\section{Стаття надійшла до редакції: 23.12.19}

\section{STATE REGULATION OF THE RECYCLING OF HOUSEHOLD WASTE IN ECONOMIC ECOLOGY}

Nataliia Levchenko, Doctor of Sciences of Public Administration, Associate Professor National University "Zaporizhzhia Polytechnic", Zaporizhzhia, Ukraine

Zhovnirchyk Yaroslav, Doctor of Sciences of Public Administration, Associate Professor, Head of the Department of Workflow, Professor of the Department of Public Management and Administration, National Aviation University, Kyiv, Ukraine

The article focuses on the main problems of dealing with household waste. Justified the criticality of the situation of waste management and the causes of its occurrence. The necessity of finding ways to strengthen the effectiveness of mechanisms of state regulation of waste management and possibilities of implementation of European experience in domestic practice. Focused on responsibility the consolidated territorial communities for the provision of public services on waste management 
and the environment. Noted that waste recycling in foreign practice is one of the most profitable sectors of the economy. It was stated that the first attempt to the business of recycling in Ukraine ended in failure due to the lack of effective mechanisms of state regulation of waste management. Clarified the meaning of "waste" through the formation of the author's definition on restorative approach. Identified the distinctive features of waste and secondary resources. The main legislative acts on regulation of waste management and proved their inefficiency. Processed by the National waste management strategy in Ukraine by 2030 based principles for the treatment of household waste. The expediency of implementation of waste recycling on the example of Poltava in the subregion allocated in accordance with sub-regional strategies of waste management in Poltava region, developed by the European experts with the support of Deutsche Gesellschaft für Internationale Zusammenarbeit (GIZ) GmbH in the framework of the international project "management Reform in the East of Ukraine" (PN 11-2129.2-001.00). The proven need for the provision of waste recycling in the private sector of the economy that will achieve compliance taken by Ukraine of the obligations of greening the economy. Developed practical recommendations on the development of a unified territorial communities of the Concepts of interaction of united territorial communities with participants of the household waste recycling process.

Keywords: waste, municipal solid waste, municipal waste, waste recycling, greening of the economy

\section{Received: 23.12.19}

\section{References}

1. Voloshyna, O. A. \& Stetsenko, Yu. V. (2018). Problemy ta napriamy efektyvnoho upravlinnia pobutovymy vidkhodamy $\mathrm{v}$ suchasnykh umovakh. Ekonomika i suspil'stvo, \#19, 310-315. doi: https://doi.org/10.32782/25240072/2018-19-47

2. Derzhavnyj klasyfikator Ukrainy. Klasyfikator vidkhodiv DK 005-96, zatverdzhenyj nakazom Derzhstandartu Ukrainy vid 29.02.1996 \# 89. zakon/ nau.ua. Retrieved from http://www.zakon/nau.ua. 
3. Dovkillia Ukrainy za 2018. Statystychnyj zbirnyk. Derzhavna sluzhba statystyky Ukrainy. 2019. -214 p.

4. DSTU 2195-99 «Okhorona pryrody Povodzhennia z vidkhodamy»: Derzhavnyj standart Ukrainy, zatverdzhenyj nakazom Derzhstandartu Ukrainy vid 08.09.1999 \#167. zakon/nau.ua. Retrieved from http://www. zakon/nau.ua.

5. Mel'nyk, O. \& Obiiukh N. (2019). Pravovi aspekty rehuliuvannia vidnosyn u sferi povodzhennia z pobutovymy vidkhodamy na munitsypal'nomu rivni v Ukraini ta YeS v umovakh detsentralizatsii. Ekolohichne pravo. \#3. 127131.

6. Nasirov, M.F. (2019). Model of organization aland economic providing eco-project management from plastic wastere cycling. Stredoevropskyvestnikprovedu a vyzkum. \# 4(56) 13-20.

7. Natsional'na Stratehiia upravlinnia vidkhodamy v Ukraini do 2030 roku : skhvaleno Rozporiadzhenniam Kabinetu Ministriv Ukrainy vid 8 lystopada 2017 roku \#820-r. zakon5.rada.gov.ua Retrieved from: https://zakon5.rada.gov.ua

8. Pysarenko, P.V., Samojlik, M.S. \& Molchanova, A.V. (2018). Bioindykatsijna otsinka vplyvu mists' vydalennia vidkhodiv na stan navkolyshn'oho pryrodnoho seredovyscha. Visnyk Poltavs'koi derzhavnoi ahrarnoi akademii. \#1. 88-92.

9. Pravyl vyznachennia norm nadannia posluh z vyvezennia pobutovykh vidkhodiv. Nakazom Ministerstva z pytan' zhytlovo-komunal'noho hospodarstva Ukrainy vid 30.07.2010. \#259. [Rules for Determining the Standards of Provision of Services for the Removal of Household Waste. Order of the Ministry of Housing and Communal Services of Ukraine of 30.07.2010. \#259]. ]. zakon. rada.gov.ua Retrieved from https://zakon.rada.gov.ua/laws/show/z0871-10

10. Pro vidkhody : Zakon Ukrainy vid 05.03.1998 \#187/98-VR. [About waste: Law of Ukraine of 05.03.1998 \#187/98-VR]. Retrieved from https:// zakon.rada. gov.ua

11. Pro zatverdzhennia Kompleksnoi prohramy povodzhennia $\mathrm{z}$ tverdymy pobutovymy vidkhodamy u Poltavs'kij oblasti na 2017 - 2021 roky. Rishennia Poltavs'koi oblasnoi rady vid 14.07.2017. \#497 [On approval of the Comprehensive Program for Solid Waste Management in Poltava Oblast for 2017 - 2021. The decision of the Poltava regional council from of 14.07.2017. \#497]. www.oblrada.pl.ua Retrieved from http://www.oblrada.pl.ua/ ses/7/17/497.pdf 
12. Pro upravlinnia vidkhodamy. Proekt Zakonu Ukrainy vid 16.10.2019 \#2207. [Waste Management Draft Law: Draft Law of Ukraine of 16.10.2019 \#2207] w1.c1.rada.gov.ua Retrieved from http://w1.c1.rada.gov.ua

13. Provnesenniazmin do deiakykh zakoniv Ukrainy schodo stymuliuvannia vykorystannia pobutovykh vidkhodiv iak al'ternatyvnoho dzherela enerhii. Proekt Zakonu Ukrainy vid 31.07.2017. \#4835-d. [On Amendments to Some Laws of Ukraine on the Promotion of the Use of Household Waste as an Alternative Energy Source : Draft Law: Draft Law of Ukraine of 31.07.2017. \#4835-d] w1.c1.rada.gov.ua Retrieved from http://w1.c1.rada.gov.ua

14. Pro vnesennia zmin do Podatkovoho kodeksu Ukrainy (schodo opodatkuvannia rozmischennia pobutovykh vidkhodiv). Proekt Zakonu Ukrainy vid 16.06.2016 \#4836. [On amendments to the Tax Code of Ukraine (on the taxation of household waste disposal): Draft Law: Draft Law of Ukraine of 16.06.2016 \#4836]. w1.c1.rada.gov.ua Retrieved from http://w1.c1.rada.gov.ua

15. Pro vnesennia zmin do Biudzhetnoho kodeksu Ukrainy (schodo vykorystannia deiakykh vydiv ekolohichnoho podatku). Proekt Zakonu Ukrainy vid 16.06.2016 \#4837. [Amendments to the Budget Code of Ukraine (on the use of certain types of environmental tax): Draft Law: Draft Law of Ukraine of 16.06.2016 \#4837]. ips.ligazakon.net Retrieved from https://ips.ligazakon.net

16. Pro systemu zbyrannia ta utylizatsii vykorystanoi tary. Proekt Zakonu Ukrainy vid 28.12.2016 \#5614 [About the system of collection and disposal of used containers: Draft Law: Draft Law of Ukraine of 28.12.2016 \#5614] w1.c1. rada.gov.ua Retrieved from http://w1.c1.rada.gov.ua

17. Pro zhytlovo-komunal'ni posluhy. Zakon Ukrainy vid 09.11.2017 \#2189-VIII. [About housing and communal services: Law of Ukraine of 09.11.2017 \#2189-VIII]. zakon3.rada.gov.ua Retrieved from https://zakon3. rada.gov.ua

18. Pro upakovku ta vidkhody upakovky. Zakon Ukrainy vid 14.01.15 \#1742. [About packaging and packaging waste: Law of Ukraine of 14.01.15 \#1742]. w1.c1.rada.gov.ua Retrieved from https://w1.c1.rada.gov.ua

19. Pro vnesennia zmin do deiakykh zakonodavchykh aktiv Ukrainy u sferi povodzhennia z pobutovymy vidkhodamy. Zakon Ukrainy vid 05.02.2016 \#4028 [On amendments to some legislative acts of Ukraine in the field of household waste management : Law of Ukraine of 05.02.2016 \#402805.02.2016 \#4028]. search.ligazakon.ua Retrieved from https://search.ligazakon.ua 
20. Pro vnesennia zmin do Podatkovoho kodeksu Ukrainy (schodo vkliuchennia podatku za vyrobnytstvo $\mathrm{j}$ import upakovky ta tovariv v upakovtsi do ekolohichnoho podatku). Zakon Ukrainy vid 21.10.2015 \#3199-1. [On Amendments to the Tax Code of Ukraine (concerning the inclusion of the tax on production and import of packaging and goods in the packaging in the environmental tax): Law of Ukraine of 21.10.2015 \#3199-1]. w1.c1.rada.gov. ua Retrieved from https://w1.c1.rada.gov.ua

21. Subrehional'na stratehiia povodzhennia z vidkhodamy dlia Poltavs'koi oblasti. Deutsche Gesellschaft für Internationale Zusammenarbeit (GIZ) GmbH: Reforma upravlinnia na skhodi Ukrainy. PN11-2129.2-001.00 [Subrehional'naya strategiia povodzhennia z vidkhodamy dlia Poltavs'koi oblast. Deutsche Gesellschaft für Internationale Zusammenarbeit (GIZ) GmbH: Management Reform in the East of Ukraine. PN11-2129.2-001.00]. ims-ukraine.org Retrieved from https://ims-ukraine.org

22. Uhoda pro asotsiatsiiu mizh Ukrainoiu, $\mathrm{z}$ odniiei storony, ta Yevropejs'kym Soiuzom, Yevropejs'kym spivtovarystvom z atomnoi enerhii i ikhnimy derzhavamy-chlenamy, z inshoi storony : ratyfikovano Zakonom Ukrainy vid 16.09.2014 \#1678-VII. [Association Agreement between Ukraine, of the one part, and the European Union, the European Atomic Energy Community and their Member States, of the other part: ratified Law of Ukraine of 16.09.2014 \#1678-VII] zakon4.rada.gov.ua Retrieved from http://zakon4. rada.gov.ua

23. Chysel'nist' naiavnoho naselennia Poltavs'koi oblasti na 01.01.2015 roku. Statystychnyj zbirnyk. Holovne upravlinnia statystyky u Poltavs'kij oblasti. [Chysel'nist 'naiavnoho population Poltavs'koi oblast on 01.01.2015 deadline. Statystychnyj zbnyk. Holovne upravlinnia statystyky in Poltavs'kij area] pl.ukrstat.gov.ua Retrieved from http://pl.ukrstat.gov.ua

24. Chysel'nist' naiavnoho naselennia Poltavs'koi oblasti na 01.01.2016 roku. Statystychnyj zbirnyk. Holovne upravlinnia statystyky u Poltavs'kij oblasti. [Chysel'nist 'naiavnoho population Poltavs'koi oblast on 01.01.2016 deadline. Statystychnyj zbnyk. Holovne upravlinnia statystyky in Poltavs'kij area] pl.ukrstat.gov.ua Retrieved from http://pl.ukrstat.gov.ua

25. Chysel'nist' naiavnoho naselennia Poltavs'koi oblasti na 01.01.2017 roku. Statystychnyj zbirnyk. Holovne upravlinnia statystyky u Poltavs'kij oblasti. [Chysel'nist 'naiavnoho population Poltavs'koi oblast on 01.01.2017 
deadline. Statystychnyj zbnyk. Holovne upravlinnia statystyky in Poltavs'kij area] pl.ukrstat.gov.ua Retrieved from http://pl.ukrstat.gov.ua

26. Chysel'nist' naiavnoho naselennia Poltavs'koi oblasti na 01.01.2018 roku. Statystychnyj zbirnyk. Holovne upravlinnia statystyky u Poltavs'kij oblasti. [Chysel'nist 'naiavnoho population Poltavs'koi oblast on 01.01.2018 deadline. Statystychnyj zbnyk. Holovne upravlinnia statystyky in Poltavs'kij area] pl.ukrstat.gov.ua Retrieved from http://pl.ukrstat.gov.ua

27. Chysel'nist' naiavnoho naselennia Poltavs'koi oblasti na 01.01.2019 roku. Statystychnyj zbirnyk. Holovne upravlinnia statystyky u Poltavs'kij oblasti. [Chysel'nist 'naiavnoho population Poltavs'koi oblast on 01.01.2019 deadline. Statystychnyj zbnyk. Holovne upravlinnia statystyky in Poltavs'kij area] pl.ukrstat.gov.ua Retrieved from http://pl.ukrstat.gov.ua

28. Pro zakhoronennia vidkhodiv. Directive of the European Parliament and of the Council vid 26.04.1999 \#1999/31/EU [On the disposal of waste. Directive of the European Parliament and of the Council of 26.04.1999 \#1999/31/EU] eurlex.europa.eu Retrieved from https: http://eur-lex.europa.eu

29. Pro vidkhody ta skasuvannia deiakykh. Dyrektyv Directive of the European Parliament and of the Council vid 19.11.2008 \#2008/98/EU [On waste and repeal of certain Directives Directive of the European Parliament and of the Council of 19.11.2008 \#2008/98/EU] eur-lex.europa.eu Retrieved from https://eur-lex.europa.eu

30. Pro vnesennia zmin do Dyrektyvy 2008/98 “Pro vidkhody”. Dyrektyv Directive of the European Parliament and of the Council vid 30.05.2018 \# 2008/851/EU [Amending Directive 2008/98/ EU on waste. Directives Directive of the European Parliament and of the Council of 30.05.2018 \# 2008/98/EU] Retrieved from https://eur-lex.europa.eu

31. Kerivnytstvo z sotsial'noi vidpovidal'nosti (2019) ISO vid 01.11.2019 \#26000:2010 [Social Responsibility Guide. ISO of 01.11.2019 \#26000:2010.] www.iso.org/ru Retrieved from https://www.iso.org/ru 


\section{Відомості про авторів / Information about the Authors}

Левченко Наталія Михайлівна: Національний університет «Запорізька політехніка»: вул. Жуковського, 64, Запоріжжя, 63093, Україна

Nataliia Levchenko: National University "Zaporizhzhia Polytechnic", Zhukovsky str., 64, Zaporizhia, Ukraine.

ORCID.ORG./0000-0002-3283-6924

E-mail: levchenko@zp.edu.ua

Жовнірчик Ярослав Федорович: Національний авіаційний університет, просп. Любомира Гузара, 1, м. Київ, 03680, Україна

Zhovnirchyk Yaroslav: National Aviation University, Lubomyra Huzara ave. 1, Kyiv, 03680, Ukraine

ORCID.ORG/0000-0002-1378-9923

E-mail: ya.zhovnirchyk@ukr.net 